\title{
ASSIMILATION OF ICT-LED INNOVATION IN THE Public SECTOR OF BANGLADESH: AN EMPIRICAL INVESTIGATION ON SINGLE-STAGE ASSIMILATION PROCESS
}

\author{
Mohammad Jashim Uddin and Dong Huang \\ College of Public Administration, Huazhong University of Science and Technology \\ (HUST), Wuhan-430074, Hubei, PR China.
}

\begin{abstract}
ICT has become one of the major push factors for modern governments around the world for improving service delivery and gaining competitive advantage. In this study, we used the Diffusion of Innovation theory (DOI) and the Institutional theory to develop a conceptual framework to investigate the critical factors that affect the assimilation of ICT-led innovation in the public sector organizations of Bangladesh. Nine factors identified from the review of literature were then integrated into a TOE framework to establish a conceptual model for this study. Subsequently, 417 respondents from 175 public sector organizations took part in the survey. Then, an in-depth analysis was carried out. The findings of this research enrich the current literature and enhance practitioners' understanding of the decision-making processes involved in the process of assimilation. It sheds new light on how ICT-led innovation becomes shaped and routinized within organizational settings and beyond their boundaries.
\end{abstract}

\section{KEYWORDS}

Innovation, Assimilation, Diffusion, TOE framework, Information and Communication Technologies (ICT).

\section{INTRODUCTION}

Public sector governance around the globe has been under widespread criticism and debate for long due to the age-old bureaucratic system, rigidity, inflexibility, and poor performance. Many governments have embraced information and Communication Technologies-led (ICT) innovation as a rescuer from the criticisms. ICT has been regarded as an enabler of good governance, a tool to escalate efficiency, a process to improve effectiveness, and a push factor to enhance competitiveness among the organizations. But, re-engineering the age-old business process of the government is a gigantic task considering multifarious and ambiguous nature of such transformation. Challenges that ICT-driven administrative reforms and organizational renovation face include interoperability of applications and systems [1, 2], type and nature of stakeholders, diverse influence from government, society and the bureaucracy, and the low rate of successful project implementation [3]. Besides, for such renovation, according to Faroqi and Siddiquee [4], “ it demands a significant transformation of organizational structures, operational practices and mobilizations of massive human, technological and financial resources as well as realignment relationships with key stakeholders". Moreover, continuance usage of ICT initiatives is now 
International Journal of Managing Public Sector Information and Communication Technologies (IJMPICT) Vol. 10, No.1/2/3/4, December 2019

facing many challenges in developing countries as prejudiced by scholars [5, 6]. Researchers [7], Sumilo and Woong [8], Baum and Maio [9], [10] find that around 70\% of public sector organizations have failed to institutionalize the innovation initiatives successfully.

Therefore, a lot of scholars have explored the practice of innovation adoption and implementation over the past decade [11-13]. Most of the literature has dealt with the process, methods, and functionality of ICT in the profit-oriented private industrial farms in the context of electronic business incorporation [14-17]. Even though technology innovation has a significant impact on the non-manufacturing public sector organizations, a few studies have been found only dealing with the public sector. Besides, researchers have explored technology adoption as an applied problem where the concentration was given to the user acceptance [18, 19], user behavioral pattern to technology adoption [20], socio-economic and cultural aspects of technology diffusion [21-23], and post-adoption behavior of the user [24, 25]. But a little concentration was given to organizational dynamics that affect the assimilation process to accomplish full functional diffusion of ICT in the public sector [26].

This study looks at the organizational, inter-organizational, and related factors that affect the diffusion process of ICT in the public sector of Bangladesh. In this study, we define innovation as the adoption of an internally generated or purchased device, system, policy, program, process, product, or service that is new to the organization (Daft, 1982; Damanpour \& Evan, 1984; Zaltman, Duncan \& Holbek, 1973). Subsequently, the adoption of ICTs is an instance of innovation in the public sector. By assimilation, we meant the full-scale deployment of ICT in the organizational structure and later, embedded in the daily business process. It incorporates mainly the technology organization and environment (TOE) framework developed by Tornatzky, et al. [27] in association with Diffusion of Innovation theory [28] and Institutional Theory [29, 30] to find the influencing factors through empirical evidence. We tried to validate the following questions empirically:

1) What are the determinants of diffusion of innovation in the public sector organizations of Bangladesh? and

2) How do these determinants and characteristics influence the assimilation of ICT-led innovation?

We developed a model based on the theories mentioned above and under the lenses of the TOE framework. It identified nine relevant factors in the context of Bangladesh. Later, the model was tested using a data set of 417 collected from 175 public sector organizations (ministries and agencies) of Bangladesh.

This paper contributes to the existing literature by finding the key antecedents that affect the diffusion process on business value creation to public sector organizations. It aims to help the policymakers and practitioners to formulate new policies, strategies, and guidelines for coping up with the enormous challenges that the governments are facing in innovation implementation. 
International Journal of Managing Public Sector Information and Communication Technologies (IJMPICT)

Vol. 10, No.1/2/3/4, December 2019

\section{Literature REVIEW AND HyPOTHESIS DEVELOPMENT}

\subsection{Literature Review}

\subsubsection{Innovation in the Public Sector}

Innovation adoption in farms has been a much-discussed topic in the domain of Information system (IS) for long. The definition of innovation is one of the bandied issues in the global business world. The word innovation is termed as change, transformation, invention, innovation, ingenious ideas in many studies, and often used interchangeably. A researcher like Barnett [31] in the middle of the 20th century defines innovation as "the scientific invention of something new," whereas, in contrast, Carroll [32] viewed innovation as the adoption of a "social process" in the organizational system. Another researcher [33] described innovation as the absorption of a new invention, product, service, process as a "First user," and further use of the same thing is an imitation. In the recent literature, we considered innovation as an object, idea, or practice, which is perceived as new by a unit of adoption [34, 35]. In case of public sector organization, innovation denotes the inclusion of innovative things in the form of new ideas, process, management that leads to a significant change from the past organizational operations and management [36]. Mulgan and Albury [37] define public sector innovation as "the creation and implementation of new processes, products, services, and methods of delivery which result in significant improvements in outcomes efficiency, effectiveness or quality." For the huge relative benefits, most of the countries include ICT as a tool for the transformation of the existing system in the public sector $[38,39]$. This study discusses ICT as an innovation in the public sector.

\subsection{Stages of Technological Innovation Adoption}

From the core literature on innovation adoption and diffusion, we have found that the process of assimilation of ICT-led innovation in an organization is not an easy task. It needs to follow a complex process starting from the selection of the innovation, decision-making phase, and the assimilation phase. These stages have been described by different researchers differently. Damanpour and Gopalakrishnan [40] find two main pathways of innovation, which are initiation and implementation, and according to them, the key adoption occurs in between the initiation and adoption phases. They stated that the initiation process follows three vital stages- awareness, consideration, and intention. In this respect, Rogers [28] viewed that: "the process through which an individual or other decision-making association passes from first knowledge of innovation to forming an attitude towards innovation, to a decision to adopt or reject, to implementation of a new idea and confirmation of this decision." [Rogers [28], Damanpour and Gopalakrishnan [40]][Rogers [28], Damanpour and Gopalakrishnan [40]] [Rogers [28], Damanpour and Gopalakrishnan [40]] viewed that to be successful, innovation needs to be accepted and institutionalized. This study followed the model developed by Zhu, et al. [15]. Zhu, et al. [15] showed the assimilation process in 3 stages 1 . Initiation, 2. Adoption, 3. Assimilation, which is quite similar to the organizational innovation Model developed by Pierce and Delbecq [41]. From the aforesaid three-stage assimilation process, we selected the single-stage process to show the direct effect of the factors on the assimilation process. 
International Journal of Managing Public Sector Information and Communication Technologies (IJMPICT) Vol. 10, No.1/2/3/4, December 2019

\subsection{Diffusion of Innovation}

The theory of diffusion of innovation, as a theoretical lens, has been used vibrantly in the IS literature to investigate the determining factors of technology adoption and IS assimilation in farms and organizational level [28]. This theory acknowledged four factors that affect the adoption of an innovation. These include 1) the innovation 2) communication channels through which the innovation spreads 3) time it needs to be diffused, and 4) social system such as internal or external pressure the organization or individual receives. Rogers also finds different characteristics of the organization concerning individual adoption as an organization is the combination of systems with norms and procedures and the individual member. He finds 1) motivation and ability 2) compatibility, and 3) observability match with the individual characteristics of adoption. So, this study employs the diffusion of innovation theory as one of the main theories that have already been tested in IS adoption and IS projects evaluation by many researchers. This theory has manifolds capabilities in assessing the technological diffusion and implementation processes in the organization from various perspectives.

\subsection{Institutional Theory}

Many researchers have also indicated the limitation of the diffusion of innovation theory in evaluating E-Government implementation. because of its paying much focus on the individual level adoption rather than organizational aspects of the diffusion process[29, 30].Moreover, diffusion of innovation theory also doesn't pay much emphasis on the knowledge gap that derives from education, skill, hierarchy, and societal status of an individual employee[29, 30]. This study also employs institutional theory to discuss ICT innovation diffusion from an institutional perspective. An organization is a societal element that may be affected by various social, political, and technological forces from internally and externally. These coercive, normative, and cognitive forces, as identified by DiMaggio and Powell [42], influence an institution likely to embrace innovation. The institutional theory also has already been applied by many scholars [15, 43] to examine the influence in the ICT innovation arena. So, this study, along with other theories, also examines this theory in the public sector.

\subsection{Technology Organization and Environment (TOE) Framework}

An organization's decision to adopt, implement, and use technological innovation depends not only on technology but on the other two important contexts like organizational and environmental. The TOE framework by Tornatzky, et al. [27] has been used in the arena of IT innovation adoption in farms and organization levels by many researchers. Under the three broad aspects, 1. Technology 2. Organization, and 3. Environment, the framework describes the process of a farm's decision to adopt, implement, and routinized IT. As a generic theory, the TOE framework can be used for studying the IS adoption and IS innovation.

In the area of technology diffusion, the TOE framework has been used widely to assess IT adoption, IT implementation, and innovation assimilation in the farm and private sector organization's level due to its flexibility in embracing any other pertinent issues. In the arena of Electronic Data Interchange (EDI) and E-business, the TOE framework has been used broadly and empirically evaluated several models. These models have been further developed and extended by Iacovou, et al. [44], Kuan and Chau [45], Low, et al. [46]Hsu, et al. [47], Ahmadi, et al. [48] using large scale sample size. But, in assessing the public sector ICT assimilation, this 
International Journal of Managing Public Sector Information and Communication Technologies (IJMPICT) Vol. 10, No.1/2/3/4, December 2019

framework has not been tested much. So, this study will use the TOE framework to explore the determinants that affect public sector innovation assimilation in the context of a least developed country in particularly Bangladesh.

\subsection{ICT-led Innovation in Bangladesh}

For keeping pace with the global trends of public sector reform, the government of Bangladesh initiated ICT in the policy agenda to re-engineer governance and service delivery in the 1990s. Later, in 2009, Bangladesh launched vision Digital Bangladesh on the way to its journey to the Digital Era [49]. Since then, many initiatives and projects have been taken across the public sector organizations, as a part of the transformation, to facilitate service delivery for government to government, government to business, and government to citizen [50]. The purpose of Digital Bangladesh is to promote the transformation of the government's business process to fulfill its vision to be a middle-income country by 2021. Digital Bangladesh program has been regarded as a flagship program of the government based on which the government wants to attain the vision. Bangladesh's position in the recent UN-EGDI is 115 out of 193 member states of UN (overall score 0.48), which is top in the place from the list of 47 LDC countries. It is a significant improvement in comparison to previous years [51]. In the ICT development index, according to this report, Bangladesh's position is 147 out of 176 countries. According to Siddiquee [52], despite recent progress in the EGDI ranking, Bangladesh is still far behind from the countries with similar socio-economic backgrounds due to lack of coherent vision and strategies, isolated and unorganized implementation of ICT projects, poor infrastructure, and scarce of capable human resources. Similarly, Gregor, et al. [53] in their study suggested that a collaborative environment within the public sector organizations, changes in the government business process, capable and motivated bureaucracy, secured and trusted IT infrastructure, positive attitude and motivation of the employees towards the change, strong political commitment, and adequate legal framework may make the ICT initiative successful in Bangladesh. In Bangladesh, a few types of research have been carried out by academia on technology diffusion, e-government adoption, and innovation in the public sector. Most of the previous studies have focused on a specific innovation acceptation and its operation. A little has been explored on IT assimilation from the public sector perspective. Through empirical investigation, this study tries to fill up this gap.

\section{Conceptual Model and Hypothesis DevelopMent}

\subsection{Conceptual Model}

This study develops a conceptual model using the TOE framework to understand the effects of various technological, organizational, and environmental contexts on the diffusion of and assimilation of technological innovation. From Zhu, et al. [15]'s multi-stages innovation process, this study has taken the single-stage process 'assimilation', to examine the effect under the lens of the TOE framework with the institutional theory and theory on diffusion of innovation. Previous researchers identified many factors using the TOE framework in examining ICT integration. Going through the prominent literature on ICT integration, we identified nine relevant factors associated with ICT innovation in the context of Bangladesh. It examines the effect of these nine factors under three broad categories within the TOE framework to find out the level of

effectiveness of the factors with the assimilation process. 
International Journal of Managing Public Sector Information and Communication Technologies (IJMPICT)

Vol. 10, No.1/2/3/4, December 2019

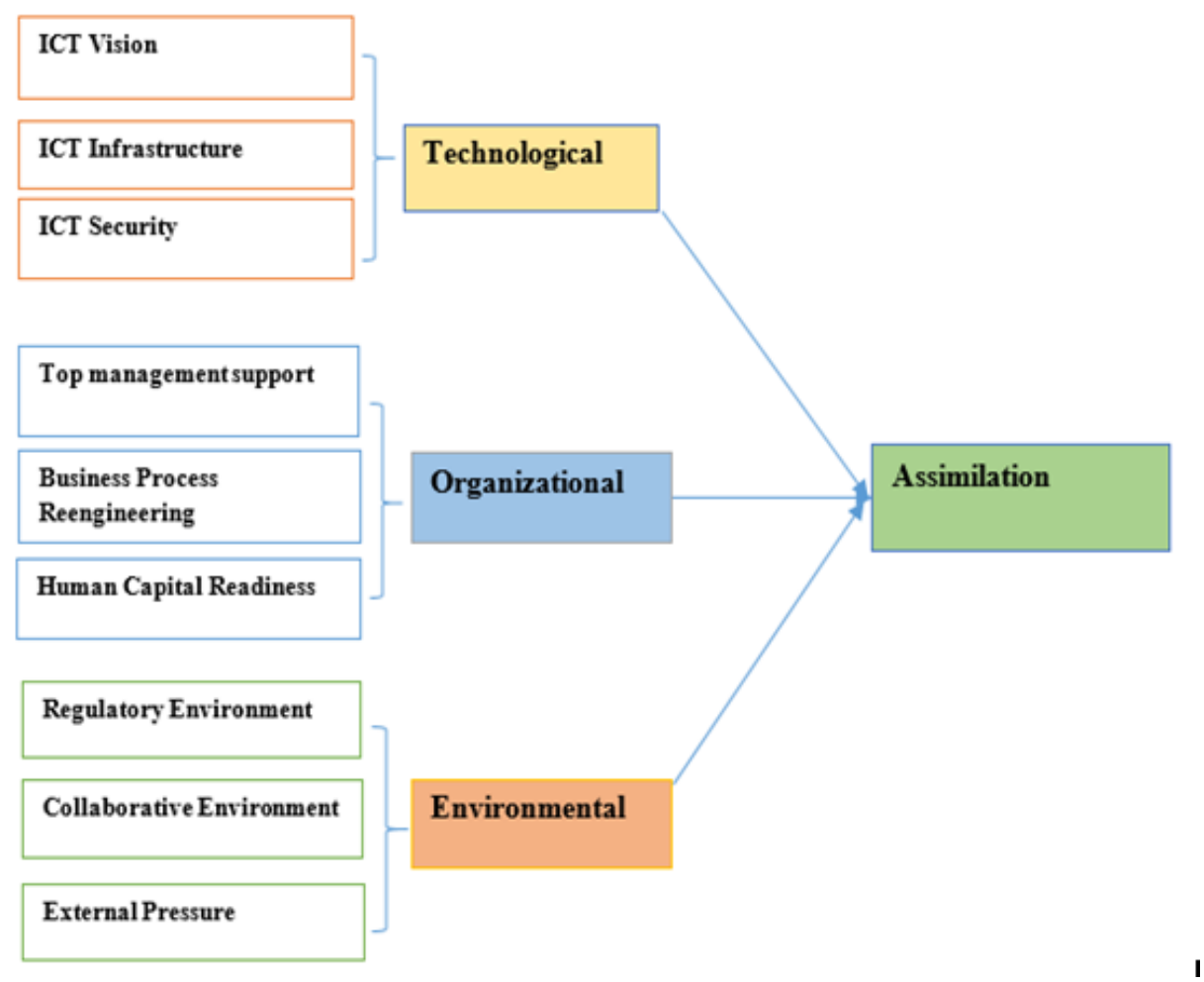

Figure:1 Research Model: Assimilation of ICT-led Innovation

\subsection{Hypothesis Development}

\subsubsection{Technological Context}

Technology is the main precondition for the development and accomplishment of ICT-led initiatives [54]. The benefits of e-government are hampered if there remain technical barriers in the adoption stage of e-government. Proper strategy and vision, along with robust ICT infrastructure, always lead to the successful integration of ICT in the organization [55]. Three factors have been selected under this context: ICT Vision, ICT infrastructure, ICT Security.

\section{ICT vision}

Vision denotes the ultimate target of an organization that it aims at achieving. A vision provides a direction for the organization to achieve in the long run. Wills (1994) defines vision as an emotional force that drives an organization to achieve its aim. A vision needs to be- coherent with the future attainment, powerful, realistic, and clear. Specific action plans with goals and objectives are to be set to attain the vision. Adoption and assimilation of ICT-led innovation require a clear vision [54]. So, it needs to be designed, considering the strengths and weaknesses of a particular country or organization [56]. Many governments have failed to materialize the innovation successful due to a lack of strategy and vision [53]. So, we hypothesize that:

$\mathrm{H}_{1}$ : ICT vision has a positive influence on the extent of ICT-led innovation assimilation 
International Journal of Managing Public Sector Information and Communication Technologies (IJMPICT)

Vol. 10, No.1/2/3/4, December 2019

\section{ICT Infrastructure}

ICT infrastructure refers to the necessary technological foundation like hardware, software, shared infrastructure, collective services, and IT expertise on which the IT system of an organization interacts within and across organizations. The technologically advanced organization tends to assimilate ICT faster than others. The availability of required infrastructure drives the egovernment development. The e-government survey [51] also reflects that the economically developed countries are at the top of the ranking, whereas the developing and least developed countries are at the bottom of the list due to infrastructure [51]. ICT Setup is the precondition in the stage of adoption and then assimilation. Therefore, the hypothesis stands as follows:

$\mathrm{H}_{2}$ : A higher level of infrastructural competence positively affects the extent of ICT-led innovation assimilation

\section{ICT Security}

Information System (IS) security has have been a matter of concern for many public organizations that have adopted IT-based service delivery and online transactions[57][58]. Users of the IS system from both ends need to be assured that the system is not vulnerable to internal and external threats. And privacy is well protected and is safe from all kinds of dangers like viruses, worms, malware, botnets, key loggers, scams and phishing hacking, malicious programs $[59,60]$. A secured IS system and positive perceptions about the safety of users' data, transactions, and communications lead to the success of IT adoption [61]. The greater extent of the security system increases the process of assimilation [62, 63]. So, the following hypothesis can be extracted from the above discussion:

$\mathrm{H}_{3}$ - Better IT security has a positive effect of ICT-led innovationassimilation

\subsubsection{Organizational Context}

Organizational context refers to tangible and intangible assets an organization requires at the time of initiation, adoption, and assimilation of innovation [15]. A technology-assisted business process requires the organizational enablers and business process re-shaping for integration to provide commendable output $[64,65]$. Three factors have been selected under the organization context for this study: top management support, business process reengineering, and employee readiness are crucial in the assimilation process.

\section{Top Management Support}

The assimilation of technological innovation is difficult to achieve without widespread support from the top management. Top management includes all managers of an organization who are responsible for implementing organizational policies, rules, and guidelines. On the other hand, top management support refers to the understanding of nature, functions, and governance of ICT by the top management and their support during initiation and adoption stages through time, direction, motivation, and required financial commitment. In inter-organizational assimilation of IS, long term business vision, sharing of ideas, and top managers' interactions among themselves are significantly crucial for business value creation [66]. Hence, 
International Journal of Managing Public Sector Information and Communication Technologies (IJMPICT) Vol. 10, No.1/2/3/4, December 2019

$\mathrm{H}_{4^{-}}$Top Management Support is positively related to the extent of ICT-led innovation assimilation

\section{Business Process Reengineering}

The diffusion of innovation has always catalyzed many external and internal changes in organizations. But, according to Scholl [67], before executing any change, the top management needs to analyze, evaluate, and review the prevailing business process in order to find the applicability and relevancy of such alteration. Researchers find that public sector BPR is more critical than the private sector considering the legal, financial, and administrative modifications an organization has to undergo $[68,69]$. Moreover, the size, nature, and culture of an organization influence the change management. Transforming does not only allows the incorporation of technology, but it also provides changes in structure and practices as well [70]. Many governments have failed to manage the changes well as BPR is not so easy to accomplish in the public sector. So, it is a significant factor that influences organizational ICT integration. Therefore, this study hypothesizes that,

$\mathrm{H}_{5}$ : BPR positively influences the assimilation of ICT-led innovation

\section{Human Capital Readiness}

Employees of an organization are the most challenging components of ICT assimilation without whose skills all strategies, plans, and infrastructure are incomplete. OECD defined human capital as "knowledge, skills, competencies, and attributes embodied in individuals" [71]. Behind the machine, there is a human being who runs the technology, make decisions, and coordinate with other spheres to realize the strategy of ICT adoption. So, employees' mind-sets to the changes and attitudes and behavior with the innovation are very crucial in structural and organizational reforms [72]. Policymakers must take these issues into cognizance before implementing ICT strategies. Previous researches find that, lack of qualified IT staff, inadequate training on the use of computers and the internet, absence of effective performance appraisal system [73, 74], and lack of system ownership taking by the employee [75] caused poor performance of the egovernment. So, this study has considered employee readiness as one of the critical factors that influence ICT integration. It hypothesized that,

$\mathrm{H}_{6^{-}}$Human capital readiness on ICT positively affect the assimilation of ICT-led innovation

\subsubsection{Environmental Context}

Environmental Context refers to the factors that may influence the operating environment of ICT adoption and assimilation. Innovation always faces extrinsic and intrinsic pressure on the way to assimilation. Three factors are associated with the technology that influences the assimilation process externally and internally: regulatory environment, collaborative environment (supportive environment), and external pressure.

\section{Regulatory Environment}

The regulatory environment here denotes the rules, acts, strategies, policies, and regulations a public sector organization needs to adapt. These play as building blocks for an organization in 
International Journal of Managing Public Sector Information and Communication Technologies (IJMPICT) Vol. 10, No.1/2/3/4, December 2019

ICT integration. Before implementing ICT-enabled services, there should have regulatory protection for the government and as well as for the stakeholders, including citizens, to reassure them. Legal protection will encourage users to adapt to the new system and protect their rights. Besides, before the initiation of inter-organization ICT assimilation, changes must come-up with legal backup for accelerating the progress. So, it can be hypothesized that,

$\mathrm{H}_{7-}$ A supportive regulatory environment positively influences the assimilation of ICT-led innovation.

\section{Collaborative Environment}

Government organization is inter-dependent, inter-connected, and inter-related on various issues relating to public service delivery, government data and information sharing, inter-operability, inter-infrastructure related matters, and so on. A successful inter-organizational ICT diffusion depends on the relationships among the organizations [76]. Organizational business value can be maximized if there exists a good connection, communication, and sharing. Lack of well-designed mechanism for inter-operability, adequate collaboration, fragmented services, and bureaucratic rigidness affects negatively on inter-organization diffusion [77].

$\mathrm{H}_{8^{-}}$A collaborative environment positively affects the assimilation of ICT-led innovation

\section{External Pressure}

External pressures comprise of expectations from the demand side, political government's commitment, partner organizations' demand, social characteristics, stake-holders' expectation, and competitive environment arises from the market. It can, therefore, be regarded as one of the most influencing factors in e-government development in the developing countries [78].

$\mathrm{H}_{9}$ - External pressure positively affect the assimilation of ICT-led innovation

\section{RESEARCH METHODOLOGY}

\subsection{Sample Selection and Survey Methods}

Given that the purpose of the study is to identify and examine the factors that influence the assimilation of ICT-driven innovation in the public sector, we deployed survey methodology to empirically test and analyze the conceptual model, and to answer the research questions. Initially, we conducted a pilot survey with the public sector executives, IT professionals, and egovernment project specialists of the A2I project under UNDP, Bangladesh to seek their feedback on the survey instrument. A total of 43 employees from ministries and agencies across the country participated in the pilot survey. We asked for their comments on the language, length, clarity, and completeness of each item reviewed under the area of substantiality, scope, and objectivity. The pilot survey results did not provide any significant recommendations. However, several suggestions have been integrated into the development of the questions. The survey questionnaire was administered in English as all of the participants are graduate, and well known to the critical terms of the IS and have good command over English. The meaning of some of the keywords was written in Bangla language for a better understanding of the ideas. 
International Journal of Managing Public Sector Information and Communication Technologies (IJMPICT) Vol. 10, No.1/2/3/4, December 2019

We distributed the final survey questionnaire through the online setting to all the government ministries, divisions, departments, and agencies that have incorporated ICT in the business process of the organizations. Respondents were selected based on their ability to talk about ICT related business and its diffusion process. Respondents were stratified by at least one manager responsible for ICT management and 1 IT official from each organization. Where IT personnel were not available, the officer in charge of the ICT cell responded to the survey questionnaire. We distributed 525 questionnaires ( 3 to each organization) to all 175 organizations that have adopted ICT in their business process. Finally, we received 443 responses out of 525 questionnaires, and the response rate was more than $83 \%$. Among the responses, 26 were dropped due to inconsistency and incompleteness. Finally, we obtained 417 datasets.

\subsection{Measurement of Constructs}

Measurements items of this study were developed in connection with the literature review, hypotheses, and the conceptual model. After reviewing a wide-range of literature, this study has taken a total of 10 variables and 39 measurement items in designing the survey questionnaire. The previous studies by $[15,79]$ have been followed as much as possible for developing the measurement items of this study. Some items were modified to be matched with the assimilation of ICT. A five-point Likert scale with values ranging between 1 (highly insignificant or strongly disagree) and 5 (Highly Significant or Strongly agree). Some items were measured in percentage to understand the volume and depth of the use. The full measurement items are shown in the appendix-1.

\subsection{Dependent Variable}

The dependent variable assimilation has been measured by asking three questions consisting of volume, diversity, and depth. These three measurement scales have been used earlier in many information systems (IS), EDI, and E-commerce studies [80, 81]. The scale volume indicates the percentage of total public services are being delivered with the help of ICT, depth represents the percentage of functional areas such as decision making process, diversity refers to the areas other than the public services like online data and information sharing that are being offered through the use of ICT.

\subsection{Independent Variable}

Technological Context: The three variables under the technology category 1) ICT vision, 2) ICT infrastructure, and 3. ICT security has collectively reinforced and figured out the total technological condition of the assimilation process. Subsequently, they also represent the total competence of the technological construct ([15]. A total of 11 items have been deployed to measure the technological context. ICT vision was measured by three items adapted from Abdalla [54]1. availability of vision, 2. initiatives to achieve the vision with setting objectives and action plan, 3. engagement of employees in designing strategy and action plan. The ICT infrastructure was measured by fouritems 1 . organizational infrastructural capability, 2. connectivity with departments and agencies, 3. operationalization facility, and 4) data and information sharing facilities with partners [54, 63]. On the other hand, for measuring ICT security knowledge, organization's measures, and users' trust and satisfaction on the existing security altogether, these three items have been chosen. 
International Journal of Managing Public Sector Information and Communication Technologies (IJMPICT)

Vol. 10, No.1/2/3/4, December 2019

\subsection{Organizational Context}

Under organizational factors again, we have chosen three variables. Top management support denotes how much senior leaders of the organization are supportive of the innovation integration process. It was measured by four items 1. Awareness, 2. Capability, 3. Commitment, and 4. Supportability of the top managers[63, 82, 83]. Secondly, organizational competence was measured by four items 1 . Willingness to change, 2. Size and nature of the organization, 3 . Organizational Culture and values; 4. Resources for initiating transformation [82, 84]. The third variable under the organizational factor is human capital readiness. Human capital readiness refers to the competence of the employees to well come and implement the changes. It is measured by the extent of knowledge, willingness, competence, training, motivation, and reward and punishment system. The six items were adopted from [82].

\subsection{Environmental Context}

Public institutions are significantly affected by external and internal dynamics which tempt and create pressure to use and adopt information system [15, 62]. Three variables have been selected under the environmental context to find the extent of the pressure. The regulatory environment represents 1 . Whether the existing laws and legal aspects are adequate, 2 . The necessity of new rules and policies, and 3. extent to political government's support. Collaboration among the partners plays vital roles in the diffusion of innovation as this process needs multi-stakeholders' engagement in realizing the vision. The collaborative environment was measured by the extent of cooperation, willingness to respond, awareness and commitment, readiness, legal bindings of the partners in the implementation process. The last variable under this context is Environmental Pressure. It is measured by three items, which include 1. the degree of pressure the organization receives from the citizens, 2. The degree of pressure from stake-holders, 3. the extent of competition with the partner organizations, 4 . The extent of pressure the organization receives for providing better and time-bound service delivery.

\section{Results}

In this study, we conducted the data analysis in two faces. First, we assessed the conceptual model and then the hypotheses. As this study aims to assess the single-stage model and the TOE framework as a whole, we chose SPSS and Smart PLS to see the magnitude of each of the constructs on ICT-led innovation assimilation. We tested the model and found that most of the hypotheses are reflective.

\subsection{Results of the Measurement Model}

Our measurement model was assessed through checking reliability, convergent validity, and discriminant validity in order to know stability and internal consistency within a construct [85].It shows that all of the constructs except BPR have composite reliability, which is greater than the suggested value of 0.7 [85]. It indicates that the measurement indicators are reliable. The Cronbach's alpha for BPR is 0.658 , which is slightly lower than 0.7. Even, according to Werts [86], it is still acceptable.

The table-1 below signifies the associations among the variables used for this study. The aggregated results portray that all the variables (dependent and independent) are positively 
International Journal of Managing Public Sector Information and Communication Technologies (IJMPICT)

Vol. 10, No.1/2/3/4, December 2019

correlated with each other, and all are significant at $0.01 \%$ level. Besides, it shows that the higher level of correlation between the variables RE and HCR (0.666); whereas the lowest level of relationship exists between the variables INS and EP (0.350).

Table 1. Descriptive Statistics and measurement model

\begin{tabular}{|l|l|l|l|l|l|l|l|}
\hline Constructs & Code & Items & Mean & $\begin{array}{l}\text { Standard } \\
\text { Deviation }\end{array}$ & Cronbach $\boldsymbol{\alpha}$ & CR & AVE \\
\hline ICT Vision & ICTV & 3 & 3.7250 & .77249 & .825 & 0.90 & 0.74 \\
\hline ICT Infrastructure & ICTI & 4 & 3.4790 & .84425 & .850 & 0.91 & 0.77 \\
\hline ICT Security & ICTS & 4 & 3.1205 & .86326 & .846 & 0.90 & 0.69 \\
\hline $\begin{array}{l}\text { Top Management } \\
\text { Support }\end{array}$ & TMS & 4 & 3.6661 & .85739 & .884 & 0.92 & 0.69 \\
\hline $\begin{array}{l}\text { Business Process } \\
\text { Reengineering }\end{array}$ & BPR & 4 & 3.5947 & .64907 & .658 & 0.79 & 0.74 \\
\hline $\begin{array}{l}\text { Human Capital } \\
\text { Readiness }\end{array}$ & HCR & 5 & 3.0232 & .81911 & .881 & 0.79 & 0.50 \\
\hline $\begin{array}{l}\text { Regulatory } \\
\text { Environment }\end{array}$ & RE & 3 & 3.4980 & .78007 & .775 & 0.91 & 0.63 \\
\hline $\begin{array}{l}\text { Collaborative } \\
\text { Environment }\end{array}$ & CE & 5 & 3.1060 & .69958 & .743 & 0.87 & 0.69 \\
\hline External Pressure & EP & 4 & 3.3345 & .72447 & .717 & 0.88 & 0.51 \\
\hline Assimilation & ASSI & 3 & 2.8513 & .93983 & .852 & 0.88 & 0.51 \\
\hline
\end{tabular}

Table:2- Correlation Matrix

\begin{tabular}{|l|l|l|l|l|l|l|l|l|l|l|}
\hline $\begin{array}{l}\text { Variab } \\
\text { les }\end{array}$ & ICTV & ICTI & ICTT & TMS & BPR & HCR & RE & CE & EP & ASSI \\
\hline ICTV & 1 & & & & & & & & & \\
\hline ICTI & $.548^{* *}$ & 1 & & & & & & & & \\
\hline ICTS & $.508^{* *}$ & $565^{* *}$ & 1 & & & & & & & \\
\hline TMS & $.666^{* *}$ & $.629^{* *}$ & $.555^{* *}$ & 1 & & & & & & \\
\hline BPR & $.559^{* *}$ & $.566^{* *}$ & $.535^{* *}$ & $.645^{* *}$ & 1 & & & & & \\
\hline HCR & $.586^{* *}$ & $.632^{* *}$ & $.586^{* *}$ & $.662^{* *}$ & $.603^{* *}$ & 1 & & & & \\
\hline RE & $.544^{* *}$ & $.547^{* *}$ & $.476^{* *}$ & $.596^{* *}$ & $.563^{* *}$ & $.666^{* *}$ & 1 & & & \\
\hline CE & $.506^{* *}$ & $.578^{* *}$ & $.556^{* *}$ & $.540^{* *}$ & $.570^{* *}$ & $.728^{* *}$ & $.624^{* *}$ & 1 & & \\
\hline EP & $.318^{* *}$ & $.293^{* *}$ & $.395^{* *}$ & $.325^{* *}$ & $.413^{* *}$ & $.321^{* *}$ & $.300^{* *}$ & $.386^{* *}$ & 1 & \\
\hline ASSI & $.496^{* *}$ & $.496^{* *}$ & $.495^{* *}$ & $.480^{* *}$ & $.476^{* *}$ & $.549^{* *}$ & $.404^{* *}$ & $.489^{* *}$ & $.350^{* *}$ & 1 \\
\hline
\end{tabular}

** Correlation is significant at the 0.01 level (2-tailed).

\subsection{Results of the Structural Model}

Table-2 represents the linear regression analysis, which depicts the effects of the independent variables on the dependent variable (Assimilation). The regression table shows that IVS $(\beta=.103$, $\mathrm{P}<0.01)$ ICTINFRA $(\beta=.136, \mathrm{P}<0.01)$, ITS $(\beta=.142, \mathrm{P}<0.01)$, TMS $(\beta=.145, \mathrm{P}<0.0)$, BPR $(\beta=.201, \mathrm{P}<0.01), \operatorname{HCR}(\beta=.257, \mathrm{P}<0.01), \operatorname{RE}(\beta=.087, \mathrm{P}<0.01), \mathrm{PCR}(\beta=.137), \mathrm{P}<0.01 \quad(\beta=.462$, $\mathrm{P}<0.01)$ positively affect the assimilation of ICT. On the other hand, EP $(\beta=-.094, \mathrm{P}<0.01)$ negatively affects the Assimilation of ICT. Besides, it also proved that the effect of INTINFRA, IST, TMS, BPR, HCR, and CE are positive and significant at the level of $0.029 \%, 0.014 \%$, 
International Journal of Managing Public Sector Information and Communication Technologies (IJMPICT) Vol. 10, No.1/2/3/4, December 2019

$0.004 \%, 0.003 \%, 0.001 \%$, and $0.016 \%$ on Assimilation of ICT-led innovation. Besides, the effect of IVS and RE are positive but insignificant at the level of $0.210 \%$ and $0.289 \%$, respectively. The effect of EP on the dependent variable is negative and insignificant at the level of $-0.164 \%$. From the above discussion, it can be summarized that, in this study, the hypotheses ICT infrastructure $\left(\mathrm{H}_{2}\right)$, ICT Security $\left(\mathrm{H}_{3}\right)$, Top Management Support $\left(\mathrm{H}_{4}\right)$, Business Process Reengineering $\left(\mathrm{H}_{5}\right)$, Human Capital Readiness $\left(\mathrm{H}_{6}\right)$, and Collaborative Environment $\left(\mathrm{H}_{8}\right)$ are accepted. On the other hand, hypotheses ICT vision $\left(\mathrm{H}_{1}\right)$, Regulatory Environment $\left(\mathrm{H}_{7}\right)$, and External Pressure $\left(\mathrm{H}_{9}\right)$ are not accepted.

Table:3 Regression on Assimilation

\begin{tabular}{|c|c|c|c|c|c|}
\hline \multirow[t]{2}{*}{ Model } & \multirow{2}{*}{$\begin{array}{c}\text { Unstandardized } \\
\beta\end{array}$} & \multirow{2}{*}{$\begin{array}{l}\text { Coefficients } \\
\text { Std. Error }\end{array}$} & \multirow[t]{2}{*}{ Sig. } & \multicolumn{2}{|c|}{ 95.0\% Confidence Interval for B } \\
\hline & & & & Lower Bound & Upper Bound \\
\hline (Constant) & -.374 & .239 & .119 & -.845 & .096 \\
\hline IVS & .103 & .082 & .210 & -.058 & .264 \\
\hline ICTINFRA & .136 & .062 & .029 & .014 & .259 \\
\hline IST & .142 & .057 & .014 & .029 & .255 \\
\hline TMS & .145 & .050 & .004 & .046 & .243 \\
\hline BPR & .201 & .067 & .003 & -.070 & .332 \\
\hline HCR & .257 & .078 & .001 & .104 & .409 \\
\hline $\mathrm{RE}$ & .087 & .082 & .289 & .074 & .039 \\
\hline PCR & .137 & .057 & .016 & -.026 & .249 \\
\hline EP & -.094 & .068 & .164 & -.227 & .039 \\
\hline
\end{tabular}

a. Dependent Variable: InnovationAssimilation

b. $* * * \mathrm{P} \leq 0.001, * * \mathrm{P} \leq 0.01, * \mathrm{P} \leq 0.05$, (two-tailed)

\section{MAJOR FINDINGS AND DISCUSSIONS}

The main purpose of the study is to find out the determinants of ICT-led innovation assimilation in the public sector of Bangladesh. The results of this study are consistent with the previous studies in this area and the theoretical foundation developed in the literature review. It also provides empirical evidence in the domain of innovation assimilation. The diffusion of innovation theory and the institutional theory have been deployed in this study under the TOE framework to build the conceptual model. It explored the association of the factors under the TOE framework with the innovation assimilation process.

The findings show that ICT infrastructure, ICT security and trust, top management support, business process reengineering, human capital readiness, and collaborative environment are significant enablers for ICT-led innovation assimilation in the public sector. The findings reflect the previous findings by Zhu, Pudjianto, and Prem Kumar [15, 55, 63]. This study also finds that human capital readiness and ICT infrastructure have the strongest, and external pressure has the weakest relationship with the assimilation process. The findings of the study also reveal that though ICT vision and strategy and ICT regulatory have a significant effect on innovation assimilation, yet the hypotheses are not accepted in the model fit. Interestingly, our study finds that external pressure negatively affects the assimilation process. The reasons may be either due to 1 . illogical pressure from the political leaders to the civil servants, 2 . stake-holders' mistrust 
International Journal of Managing Public Sector Information and Communication Technologies (IJMPICT) Vol. 10, No.1/2/3/4, December 2019

and non-cooperation, and 3. the inability of the citizen to access to information; or the public non responsive attitude of the public sector.

The result also demonstrates that among the three contexts of the TOE framework, the organizational context affects the most in the process of assimilation. It shows that top management supports business process reengineering, and human capital readiness significantly affects the assimilation. So, it suggests that for organizational ICT-led innovation assimilation, the focus should be given more on the organizational factors.

Variables under technological factors depict the second most influential relationship in this study. It denotes that organizational factors, along with robust ICT infrastructure, security measures, and inter-organizational collaboration, will lead to the success of the assimilation process. This finding is consistent with the previous findings of [11,63].

Even though the constructs ICT vision and regulatory environment are found to have positive on the assimilation, yet the effects are not significant. It might be not apparent to the respondents about the organizational vision, or they were not aware of it. For the regulatory environment, the reasons might be the compliance of the existing legal framework is good enough [87], or it doesn't match well with the organization's intention to adopt technology [88]. A well-framed regulatory framework is likely to be significant in the assimilation process [89]. The regulatory body may emphasis to form the regulations in a manner which will maximize the positive and minimize the adverse influence for ICT-led innovation. Before framing, assimilation strategy organization may emphasize it.

In many studies on technology assimilation, it is found that, longitudinal external pressure positively affects technology assimilation in the organization [80]. The institutional theory also suggests that external pressure tends to push an organization to change. But in this study, we found that external pressure affects the innovation assimilation stage negatively. It again clearly echoes the findings of Wang [90], who viewed that, when the use of technology is to meet up only the internal needs motivated by internal expectations, the assimilation process remains low, and later, when the organization's assimilation process gradually improves, the external pressure increases positively and significantly. As the significance level of the variables reflects that the assimilation process is still at a low level in Bangladesh, as per the above discussion, the negative effect of external pressure is reasonable.

\subsection{Implications/Significance}

The study results have several theoretical and practical contributions to academia, policymakers, and practitioners. They should get the benefit from the findings of the study in understanding more about the factors affecting ICT-led innovation in the public sector.

Managerial Implications: This framework will help the policymakers to develop policies concerning innovation assimilation. Subsequently, this study finds that human capital readiness is the most crucial aspect of innovation assimilation. So, more focus should be given by the policymakers to make the persons behind the machine to be ready to face the change process. Moreover, ICT infrastructure should be developed in a way that can boost the speed of the assimilation process. Top management also should acknowledge their vital rules in resource allocation and other associated activities. Besides, the results showed that ICT vision and strategy 
International Journal of Managing Public Sector Information and Communication Technologies (IJMPICT) Vol. 10, No.1/2/3/4, December 2019

and regulatory aspects, though, are not statistically significant, but researchers pointed out their consequences in the long run. The policymakers should be aware of the possibility of their negative effect on the performance if not appropriately addressed.

Theoretical Implications: The conceptual framework developed for this study is unique. It adopts diffusion of innovation theory and institutional theory under the TOE framework, which has not been extensively applied in the domain of ICT-led innovation assimilation in particularly in Bangladesh. It extends previous theoretical contributions to ICT-led innovation assimilation in the context of the public sector by adding new factors. Besides, the findings of this study advocate a necessity for using upgraded measurement items and conceptualizations of the factors in the current context.

\subsection{Limitation and Future Directions}

The data of this study has been collected from a single country, and the participants represent specific country organizations only. Moreover, the organizations also do not represent all the organizations. So, future research may test this model in the context of multiple other countries. Furthermore, this survey was limited to ministries and agencies situated in the capital city only. It infers that the findings may not take a broader overview of all the public sector organizations of Bangladesh. Researchers in the future may select a variety of organizations around the country in terms of size and type. Future research may also ascertain organizational size and type as factors in the ICT-led innovation assimilation studies.

In the technology adoption literature, the long-standing question is, "who should rate the innovation if the potential adopter is not an individual, but an organization?" (Tornatzky \& Klein, 1982 , p. 41). The survey data for this study were collected from only two representatives from a single organization. So, future research may take multiple units to represent an organization to have a more comprehensive view of the assimilation process.

This study focused on a single stage assimilation process under the TOE framework due to time constraints. In the conceptual framework, the study has taken ICT security and trust, a collaborative environment, and external pressure as the news constructs. The future researchers may replicate this framework and test it in their specific organizational context. It may also adopt new measurement items based on the socio-cultural background, actual capacity, and capability of their organization. Additionally, future research may test a multi-stage assimilation model for advancing the literature on innovation assimilation.

\subsection{Conclusion}

Grounded in the Diffusion of Innovation theory (DOI), the institutional theory, and the Technology-Organization-Environment (TOE) framework, this study developed a theoretical model to empirically investigate the critical factors that affect the assimilation of ICT-led innovation in the public sector organizations of Bangladesh. The findings of the study have enhanced our understanding of the factors affecting the assimilation of ICT-led innovation in public sector organizations. It also enriches the current literature and augments practitioners' understanding of the decision-making processes involved in the process of assimilation of public sector ICT innovation. It sheds new light on how ICT-led innovation becomes shaped and institutionalized within organizational settings and beyond their boundaries. 
International Journal of Managing Public Sector Information and Communication Technologies (IJMPICT) Vol. 10, No.1/2/3/4, December 2019

\section{REFERENCES}

[1] T. A. Pardo, T. Nam, and G. B. Burke, "E-government interoperability: Interaction of policy, management, and technology dimensions," Social Science Computer Review, vol. 30, pp. 7-23, 2012.

[2] W. Cellary and S. Strykowski, "E-government based on cloud computing and service-oriented architecture," in Proceedings of the 3rd international conference on Theory and practice of electronic governance, 2009, pp. 5-10.

[3] D. C. Wyld, Moving to the cloud: An introduction to cloud computing in government: IBM Center for the Business of Government, 2009.

[4] M. G. Faroqi and N. A. Siddiquee, "Limping into the information age: challenges of e-government in Bangladesh," The Journal of Comparative Asian Development, vol. 10, pp. 33-61, 2011.

[5] Å. Grönlund and T. A. Horan, "Introducing e-gov: history, definitions, and issues," Communications of the association for information systems, vol. 15, p. 39, 2005.

[6] M. Warkentin, D. Gefen, P. A. Pavlou, and G. M. Rose, "Encouraging citizen adoption of egovernment by building trust," Electronic markets, vol. 12, pp. 157-162, 2002.

[7] B. W. Pudjianto and Z. Hangjung, "Factors affecting e-government assimilation in developing countries," 2009.

[8] S. Sumilo and K. Woong, "Structurational Analysis of IT-Enabled Organizational Change: A Case of Public Organization in Singapore," Retrieved on October, vol. 5, p. 2007, 2004.

[9] C. Baum and A. Maio, "Gartner's Four Phases of E-Government Model, Gartner," Inc., Research Note, Tutorial TU-12-6113, 2000.

[10] R. Heeks, Most e-government-for-development projects fail: How can risks be reduced? vol. 14: Institute for Development Policy and Management, University of Manchester Manchester, 2003.

[11] R. Schware and A. Deane, "Deploying e-government programs: The strategic importance of "I" before "E"," info, vol. 5, pp. 10-19, 2003.

[12] R. Traunmüller and M. A. Wimmer, "E-government at a decisive moment: sketching a roadmap to excellence," in International Conference on Electronic Government, 2003, pp. 1-14.

[13] V. Mayer-Schönberger and D. Lazer, "E-Gov and the Coming Revolution of Information Government," Working Paper, Belfer Center for Science and International Affairs2008.

[14] W. J. Orlikowski, "Using technology and constituting structures: A practice lens for studying technology in organizations," Organization science, vol. 11, pp. 404-428, 2000.

[15] K. Zhu, K. L. Kraemer, and S. Xu, "The process of innovation assimilation by firms in different countries: a technology diffusion perspective on e-business," Management science, vol. 52, pp. 15571576, 2006.

[16] B. Xu, "Multinational enterprises, technology diffusion, and host country productivity growth," Journal of development economics, vol. 62, pp. 477-493, 2000.

[17] D. Andrews, C. Criscuolo, and P. N. Gal, "Frontier Firms, Technology Diffusion and Public Policy," 2015.

[18] V. Aggelidis and P. Chatzoglou, "Factors Affecting Intention to Use E-government Services: The Case of Non-adopters," in Information Systems: 15th European, Mediterranean, and Middle Eastern Conference, EMCIS 2018, Limassol, Cyprus, October 4-5, 2018, Proceedings, 2019, p. 302.

[19] S.-Y. Hung, C.-M. Chang, and S.-R. Kuo, "User acceptance of mobile e-government services: An empirical study," Government Information Quarterly, vol. 30, pp. 33-44, 2013.

[20] B. Wu and X. Chen, "Continuance intention to use MOOCs: Integrating the technology acceptance model (TAM) and task technology fit (TTF) model," Computers in Human Behavior, vol. 67, pp. 221-232, 2017.

[21] M. H. Miraz, M. Bhuiyan, and M. Hossain, "Impacts of Culture and Socio-Economic Circumstances on Users' Behavior and Mobile Broadband Technology Diffusion Trends," arXiv preprint arXiv:1708.02798, 2017.

[22] R. M. Steers, A. D. Meyer, and C. J. Sanchez-Runde, "National culture and the adoption of new technologies," Journal of World Business, vol. 43, pp. 255-260, 2008.

[23] M. Jo Hatch and M. Schultz, "Relations between organizational culture, identity and image," European Journal of marketing, vol. 31, pp. 356-365, 1997. 
International Journal of Managing Public Sector Information and Communication Technologies (IJMPICT) Vol. 10, No.1/2/3/4, December 2019

[24] T. Zhou, "An empirical examination of users' post-adoption behaviour of mobile services," Behaviour \& Information Technology, vol. 30, pp. 241-250, 2011.

[25] M. Parthasarathy and A. Bhattacherjee, "Understanding post-adoption behavior in the context of online services," Information systems research, vol. 9, pp. 362-379, 1998.

[26] A. Jansen, "The Understanding of ICTs in Public Sector and Its Impact on Governance," in International Conference on Electronic Government, 2012, pp. 174-186.

[27] L. G. Tornatzky, M. Fleischer, and A. Chakrabarti, "The processes of technological innovation. Issues in organization and management series," Lexington Books. Available at http://www. amazon. com/Processes-Technological-Innovation-Organization/Management/dp/0669203483. Accessed June, vol. 10, p. 2013, 1990.

[28] E. M. Rogers, Diffusion of innovations: Simon and Schuster, 2010.

[29] M. J. Gallivan, "Organizational adoption and assimilation of complex technological innovations: development and application of a new framework," ACM SIGMIS Database: the DATABASE for Advances in Information Systems, vol. 32, pp. 51-85, 2001.

[30] K. Viswanath and J. R. Finnegan Jr, "The knowledge gap hypothesis: Twenty-five years later," Annals of the International Communication Association, vol. 19, pp. 187-228, 1996.

[31] H. G. Barnett, "Innovation: the basis of cultural change," 1953.

[32] J. Carroll, "A note on departmental autonomy and innovation in medical schools," The Journal of Business, vol. 40, pp. 531-534, 1967.

[33] H. Yao, E. Ankomah-Asare, J. Beraud, W. Akuamoah, and W. Apeanti, "Learning to innovate; the role of imitation on the innovation adoption process within innovation networks: Evidence from a developing country," in Empowering Science and Mathematics for Global Competitiveness: Proceedings of the Science and Mathematics International Conference (SMIC 2018), November 2-4, 2018, Jakarta, Indonesia, 2019, p. 424.

[34] H. De Vries, V. Bekkers, and L. Tummers, "Innovation in the public sector: A systematic review and future research agenda," Public administration, vol. 94, pp. 146-166, 2016.

[35] B. Von Stamm, Managing innovation, design and creativity: John Wiley \& Sons, 2008.

[36] J. Fagerberg, "Mobilizing innovation for sustainability transitions: A comment on transformative innovation policy," Research Policy, vol. 47, pp. 1568-1576, 2018.

[37] G. Mulgan and D. Albury, "Innovation in the public sector," Strategy Unit, Cabinet Office, vol. 1, p. 40, 2003.

[38] D. Gagliardi, G. Misuraca, F. Niglia, and G. Pasi, "How ICTs shape the relationship between the State and the citizens: Exploring new paradigms between civic engagement and social innovation," in Proceedings of the 52nd Hawaii International Conference on System Sciences, 2019.

[39] T. O. Akenroye, "Factors influencing innovation in healthcare: a conceptual synthesis," The Innovation Journal, vol. 17, p. 1, 2012.

[40] F. Damanpour and S. Gopalakrishnan, "The dynamics of the adoption of product and process innovations in organizations," Journal of management studies, vol. 38, pp. 45-65, 2001.

[41] J. L. Pierce and A. L. Delbecq, "Organization structure, individual attitudes and innovation," Academy of management review, vol. 2, pp. 27-37, 1977.

[42] P. J. DiMaggio and W. W. Powell, "The iron cage revisited: Institutional isomorphism and collective rationality in organizational fields," American sociological review, pp. 147-160, 1983.

[43] H.-J. Kim, "The shift to the service economy: causes and effects," Institute for Monetary and Economic Research, 2006.

[44] C. L. Iacovou, I. Benbasat, and A. S. Dexter, "Electronic data interchange and small organizations: adoption and impact of technology," MIS quarterly, pp. 465-485, 1995.

[45] K. K. Kuan and P. Y. Chau, "A perception-based model for EDI adoption in small businesses using a technology-organization-environment framework," Information \& management, vol. 38, pp. 507$521,2001$.

[46] C. Low, Y. Chen, and M. Wu, "Understanding the determinants of cloud computing adoption," Industrial management \& data systems, vol. 111, pp. 1006-1023, 2011. 
International Journal of Managing Public Sector Information and Communication Technologies (IJMPICT) Vol. 10, No.1/2/3/4, December 2019

[47] P.-F. Hsu, S. Ray, and Y.-Y. Li-Hsieh, "Examining cloud computing adoption intention, pricing mechanism, and deployment model," International Journal of Information Management, vol. 34, pp. 474-488, 2014.

[48] H. Ahmadi, M. Nilashi, L. Shahmoradi, and O. Ibrahim, "Hospital Information System adoption: Expert perspectives on an adoption framework for Malaysian public hospitals," Computers in Human Behavior, vol. 67, pp. 161-189, 2017.

[49] N. A. Siddiquee and M. G. Faroqi, "E-Government in Bangladesh: Prospects and Challenges," in From Government to E-Governance: Public Administration in the Digital Age, ed: IGI Global, 2013, pp. 217-232.

[50] KOICA, "e-Government Master Plan for Bangladesh," 2018.

[51] UN, "E-Government Survey: Gearing E-Government to Suppport Transformation Towards Sustainable and Resilient Societies," 2018.

[52] N. A. Siddiquee, "E-government and transformation of service delivery in developing countries: The Bangladesh experience and lessons," Transforming Government: People, Process and Policy, vol. 10, pp. 368-390, 2016.

[53] S. Gregor, A. Imran, and T. Turner, "A 'sweet spot'change strategy for a least developed country: leveraging e-Government in Bangladesh," European Journal of Information Systems, vol. 23, pp. 655$671,2014$.

[54] S. Abdalla, "An e-government adoption framework for developing countries: A case study from Sudan," Doctor of Philosphy Ph.D. Thesis, School of Applied Sciences (SAS) Cranfield University, United Kingdom, 2012.

[55] B. Pudjianto, H. Zo, A. P. Ciganek, and J. J. Rho, "Determinants of e-government assimilation in Indonesia: An empirical investigation using a TOE framework," Asia Pacific Journal of Information Systems, vol. 21, pp. 49-80, 2011.

[56] V. Ndou, "E-Government for developing countries: opportunities and challenges," The electronic journal of information systems in developing countries, vol. 18, pp. 1-24, 2004.

[57] A. S. M. Al-rawahna, S.-C. Chen, and C.-W. Hung, "The Barriers of E-Government Success: An Empirical Study from Jordan," International Journal of Managing Public Sector Information and Communication Technologies, vol. 9, pp. 1-18, 2018.

[58] T. E. Cooper, J. Nagda, and R. F. Pryor, "Method and apparatus for enabling trial period use of software products: method and apparatus for passing encrypted files between data processing systems," ed: Google Patents, 1996.

[59] T. Braun, B. C. Fung, F. Iqbal, and B. Shah, "Security and privacy challenges in smart cities," Sustainable cities and society, vol. 39, pp. 499-507, 2018.

[60] C. C. Chen, R. Shaw, and S. C. Yang, "Mitigating information security risks by increasing user security awareness: A case study of an information security awareness system," Information Technology, Learning \& Performance Journal, vol. 24, 2006.

[61] C. Stergiou, K. E. Psannis, B.-G. Kim, and B. Gupta, "Secure integration of IoT and cloud computing," Future Generation Computer Systems, vol. 78, pp. 964-975, 2018.

[62] M. D. Hossain, J. Moon, J. K. Kim, and Y. C. Choe, "Impacts of organizational assimilation of egovernment systems on business value creation: A structuration theory approach," Electronic Commerce Research and Applications, vol. 10, pp. 576-594, 2011.

[63] G. Premkumar and K. Ramamurthy, "The role of interorganizational and organizational factors on the decision mode for adoption of interorganizational systems," Decision sciences, vol. 26, pp. 303-336, 1995.

[64] N. Wang, H. Liang, S. Ge, Y. Xue, and J. Ma, "Enablers and inhibitors of cloud computing assimilation: an empirical study," Internet Research, 2019.

[65] D. Chatterjee, R. Grewal, and V. Sambamurthy, "Shaping up for e-commerce: institutional enablers of the organizational assimilation of web technologies," MIS quarterly, pp. 65-89, 2002.

[66] V. Grover and M. D. Goslar, "The initiation, adoption, and implementation of telecommunications technologies in US organizations," Journal of management information systems, vol. 10, pp. 141-164, 1993. 
International Journal of Managing Public Sector Information and Communication Technologies (IJMPICT) Vol. 10, No.1/2/3/4, December 2019

[67] H. J. Scholl, "Organizational transformation through e-government: myth or reality?," in International Conference on Electronic Government, 2005, pp. 1-11.

[68] R. L. Martín and J. M. Montagna, "Business process reengineering role in electronic government," in IFIP World Computer Congress, TC 8, 2006, pp. 77-88.

[69] J. Y. Thong, C.-S. Yap, and K.-L. Seah, "Business process reengineering in the public sector: the case of the Housing Development Board in Singapore," Journal of Management Information Systems, vol. 17, pp. 245-270, 2000.

[70] A. F. Van Veenstra, B. Klievink, and M. Janssen, "Barriers and impediments to transformational government: insights from literature and practice," EG, vol. 8, pp. 226-241, 2011.

[71] T. Healy and S. Côté, The Well-Being of Nations: The Role of Human and Social Capital. Education and Skills: ERIC, 2001.

[72] D. Dukić, G. Dukić, and N. Bertović, "Public administration employees' readiness and acceptance of e-government: Findings from a Croatian survey," Information Development, vol. 33, pp. 525-539, 2017.

[73] Y. Lin and S. Fong, "Performance evaluation management model to accelerate the development of egovernment in China," in Proceedings of the 7th International Conference on Theory and Practice of Electronic Governance, 2013, pp. 1-4.

[74] J. Chen, Y. Yan, and C. Mingins, "A three-dimensional model for e-government development with cases in China's regional e-government practice and experience," in 2011 Fifth International Conference on Management of e-Commerce and e-Government, 2011, pp. 113-120.

[75] C. M. Chan and S. L. Pan, "User engagement in e-government systems implementation: A comparative case study of two Singaporean e-government initiatives," The Journal of Strategic Information Systems, vol. 17, pp. 124-139, 2008.

[76] H.-F. Lin and S.-M. Lin, "Determinants of e-business diffusion: A test of the technology diffusion perspective," Technovation, vol. 28, pp. 135-145, 2008.

[77] N. Casalino, M. Cavallari, M. De Marco, M. Gatti, and G. Taranto, "Defining a model for effective egovernment services and an inter-organizational cooperation in public sector," in Proceedings of the 16th International Conference on Enterprise Information Systems-Volume 2, 2014, pp. 400-408.

[78] S. Abdalla, "An e-government adoption framework for developing countries: A case study from Sudan," 2012.

[79] R. L. Purvis, V. Sambamurthy, and R. W. Zmud, "The assimilation of knowledge platforms in organizations: An empirical investigation," Organization science, vol. 12, pp. 117-135, 2001.

[80] T.-P. Liang, C.-W. Huang, Y.-H. Yeh, and B. Lin, "Adoption of mobile technology in business: a fitviability model," Industrial management \& data systems, vol. 107, pp. 1154-1169, 2007.

[81] B. Massetti and R. W. Zmud, "Measuring the extent of EDI usage in complex organizations: strategies and illustrative examples," MIS quarterly, pp. 331-345, 1996.

[82] F. Mohammed, O. Ibrahim, and N. Ithnin, "Factors influencing cloud computing adoption for egovernment implementation in developing countries: Instrument development," Journal of Systems and Information Technology, vol. 18, pp. 297-327, 2016.

[83] J.-W. Lian, D. C. Yen, and Y.-T. Wang, "An exploratory study to understand the critical factors affecting the decision to adopt cloud computing in Taiwan hospital," International Journal of Information Management, vol. 34, pp. 28-36, 2014.

[84] F. N. K. ALQahtani, "Identifying the critical factors that impact on the Development of Electronic Government using TOE Framework in Saudi E-Government Context: A Thematic Analysis," Doctor of Philosophy Ph.D., School of Computer Science and Informatics, (CCSR), De Montfort University, Leichester, United Kingdom, 2016.

[85] J. Hair, R. Anderson, B. Babin, and W. Black, "Multivariate data analysis: A global perspective: Pearson Upper Saddle River," 2010.

[86] C. E. Werts, R. L. Linn, and K. G. Jöreskog, "Intraclass reliability estimates: Testing structural assumptions," Educational and Psychological measurement, vol. 34, pp. 25-33, 1974.

[87] J. R. Gil-García and T. A. Pardo, "E-government success factors: Mapping practical tools to theoretical foundations," Government information quarterly, vol. 22, pp. 187-216, 2005. 
International Journal of Managing Public Sector Information and Communication Technologies (IJMPICT) Vol. 10, No.1/2/3/4, December 2019

[88] N. Al Mudawi, N. Beloff, and M. White, "Cloud computing in government organizations: towards a new comprehensive model," in The 5th IEEE Smart World Congress, 2019.

[89] R. Brownsword, Law, Technology and Society: Reimagining the Regulatory Environment: Routledge, 2019.

[90] P. Wang, "Assimilating IT innovation: the longitudinal effects of institutionalization and resource dependence," ICIS 2008 Proceedings, p. 21, 2008. 